\title{
Morphological Focus Marking in Gùrùntùm (West Chadic)*
}

\author{
Katharina Hartmann and Malte Zimmermann \\ Humboldt-Universität zu Berlin
}

\begin{abstract}
The paper presents an in-depth study of focus marking in Gùrùntùm, a West Chadic language spoken in Bauchi Province of Northern Nigeria. Focus in Gùrùntùm is marked morphologically by means of a focus marker $a$, which typically precedes the focus constituent. Even though the morphological focus-marking system of Gùrùntùm allows for a lot of fine-grained distinctions in information structure (IS) in principle, the language is not entirely free of focus ambiguities that arise as the result of conflicting IS- and syntactic requirements that govern the placement of focus markers. We show that morphological focus marking with $a$ applies across different types of focus, such as newinformation, contrastive, selective and corrective focus, and that $a$ does not have a second function as a perfectivity marker, as is assumed in the literature. In contrast, we show at the end of the paper that $a$ can also function as a foregrounding device at the level of discourse structure.
\end{abstract}

Keywords: morphological focus marking, focus ambiguity, focus types, foregrounding

\section{Introduction}

In this paper, we present an in-depth study of focus marking in Gùrùntùm, a West Chadic language spoken in Bauchi province of Northern Nigeria. In the remainder of this section, we lay out our ideas on the notion of focus as an

* We would like to express our deep gratitude to our language consultant Al Haji Umaru Muhamed Gùrùntùm for his patience in hour-long elicitations sessions and his many insightful comments. Thanks are also due to the participants of the Africanist Colloquium at the Humboldt University Berlin and the conference on Focus in African Languages, Berlin, 6-8 October 2005, for suggestions and comments on previous versions of

Interdisciplinary Studies on Information Structure 5 (2006): 61-105

Ishihara, S., M. Schmitz, and A. Schwarz (eds.): (C)2006 K. Hartmann and M. Zimmermann 
information-structural (IS) category, and present some background information on Gùrùntùm. In section 2, we present the basic pattern of focus marking in Gùrùntùm: Focus is marked by means of a morphological focus marker $a$, which usually precedes the focus constituent. Section 3 discusses predicate focus on V/VP and focus on parts of complex NPs. We show that focus marking is subject to at least two syntactic restrictions that sometimes give rise to focus ambiguity. Section 4 shows that all types of focus (new-information, contrastive, selective, corrective) are marked alike by means of the focus marker $a$. Section 5 shows that $a$ does not have a secondary function as a perfectivity marker despite claims to the contrary in the literature. In contrast, section 6 shows that $a$ also functions as a foregrounding device at the level of discourse: It serves to highlight bounded events that contribute to the main story line of a narrative sequence. In this function, the $a$-marker often combines individual sentences into larger informational units. Section 7 concludes.

\subsection{Focus as an information-structural category}

We adopt the following definition of focus: Focus stands for that information component that is new or important in the sense that the speaker assumes it not to be shared by him and the hearer (Jackendoff 1972). We further assume, following Rooth $(1985,1992)$, that a focused constituent $\alpha\left([\alpha]_{\mathrm{F}}\right)$ invokes a set A of alternatives to $\alpha$ from which $\alpha$ is chosen. Depending on the interaction of $\alpha$ with its alternatives, a focus can be used in different ways, giving rise to several focus types: (i.) a focus expresses new-information if $\alpha$ introduces an element of A into the common ground and $\mathrm{A}$ is implicit (1a); (ii.) a focus is corrective if $\alpha$ replaces an element of $\mathrm{A}$ introduced into the common ground in the preceding context (cf.1b); (iii.) a focus is selective if $\alpha$ introduces an element of A into the 
common ground, and $\alpha$ is chosen from a subset of $\mathrm{A}$ whose members have been explicitly mentioned in the preceding context (cf.1c). Focus is called contrastive if $\alpha$ juxtaposes an element of $A$ to one or more explicitly mentioned elements of A that belong to the same syntactic category and the same semantic word field (cf.1d).

(1) a. (Which color did Peter paint his bicycle?) He painted it [blue $]_{\mathrm{F}}$. $\alpha=$ blue, $\mathrm{A}=\{$ blue, red, green, pink, $\ldots\}$

b. (Peter painted his bicycle red.) No, he painted it [blue $]_{\mathrm{F}}$. $\alpha=$ blue, $A=\{$ blue, red, green, pink,..$\}$ \}

c. (Did Peter paint his bicycle red or blue?) He painted it [blue $]_{\mathrm{F}}$. $\alpha=$ blue, $A=\{$ blue, red, green, pink,... $\}$

d. Paul painted his bicycle $[\mathrm{red}]_{\mathrm{F}}$, and Peter painted it [blue $]_{\mathrm{F}}$. $\alpha=$ blue, $A=\{$ blue, red, green, pink,..$\}$

\subsection{Background information on Gùrùntùm}

Gùrùntùm is a highly endangered language spoken by less than 10.000 people (in 1988) in the South West corner of Bauchi Province/Northern Nigeria. It belongs to the South Bauchi group of the West Chadic B-subbranch of the Chadic family (Afro-Asiatic phylum) (see Newman 1977). Linguistic information on Gùrùntùm is scarce. The two main sources are a grammatical sketch plus word list by Jaggar (1988), and a grammar by Haruna (2003). Our data were elicited from Al Haji Umaru Muhamed Gùrùntùm, an approximately 50 -year old native speaker of the Gùrdùy-Kùukù dialect.

The neutral word order in Gùrùntùm is SVO, as shown in (2) (Haruna 2003:121). Aspectual information is generally marked by independent morphemes, such as the progressive marker bà in (2) (Haruna 2003:83).

Daniel Hole for comments and discussion. 
(2) Tí bà wúm kwálíngálá.

3SG PROG chew colanut

'He is chewing colanut.'

At the phonological level, Gùrùntùm is a tone language with two level tones $\mathrm{H}$ $(')$ and L ('), plus a falling $\left(^{\wedge}\right)$ and (very rarely) a rising tone combination (Haruna 2003:26).

\section{The Basic Pattern of Focus Marking in Gùrùntùm}

This section presents the basic pattern of focus marking in Gùrùntùm. The central observation is that focus in Gùrùntùm is morphologically marked by a focus marker $a$ : With focused terms, such as arguments and adjuncts, $a$ precedes the focus constituent. A second observation concerns the phonological behaviour of the focus marker $a$ : If $a$ follows directly on the main verb, e.g. if it marks the following object for focus, it cliticizes onto the verb prosodically.

In 2.1, we show that focus marking consistently occurs with all major constituents. In 2.2, it is shown that focus marking is consistent across tenses or aspects. In 2.3, we show that the focus constituent can occur in situ or ex situ, as long as it is preceded by the focus marker $a$.

\subsection{Consistent focus marking on all major constituents}

The following data show that morphological focus marking by means of $a$ is consistent across categories in Gùrùntùm. Compare the neutral (all-new) sentence in (2), with instances of narrow constituent focus in (3) and (4). (3a) and (4a) illustrate subject focus, (3b) and (4b) illustrate focus on the direct object. Throughout, we mark the focus constituent in the Gùrùntùm examples by italics, and narrow constituent focus in the English paraphrases by capitals. 
(3) a. Á kwá bà wúm kwálíngálá-ì?

FOC who PROG chew colanut-DEF

'WHO is chewing the colanut?'
Á fúrmáyò bà wúm kwálíngálá. FOC fulani PROG chew colanut
'THE FULANI is chewing colanut.'

b. Á kããa mài tí bà wúmì? Tí bà wúm-á kwálíngálá. FOC what REL 3SG PROG chew 3SG PROG chew-FOC colanut 'WHAT is he chewing?' 'He is chewing COLANUT.'

(4) a. Á kwá bà nyòolí g $\mathrm{g}^{\mathrm{y}} \mathrm{òo}-\mathrm{i}$ ?

FOC who PROG write message-DEF

'WHO is writing the message?'
Á Hàfsá bà nyòolí g òo-i.
FOC Hàfsá PROG write message-DEF
'HAFSA is writing the message.'

b. Á kã̃a mài tí bà nyòolí? Tí bà nyòol-á $g^{y}$ òo. FOC what REL 3SG PROG write 3SG PROG write-FOC message 'WHAT is he writing?' 'He is writing A MESSAGE.'

Notice that the focus marker prosodically cliticizes onto the immediately preceding verb in (3b) and (4b). There are two kinds of evidence for cliticization of the focus marker on the preceding verb: First, verb and focus marker are prosodically phrased as one unit, and the following constituent as another. This means that if there is a pause in the clause, it will be located between focus marker and object, and not between verb and focus marker. Second, the final vowel of the verb is elided, as is normally the case before direct objects, and the focus marker is assigned the tone of the elided vowel, thus preserving the underlying tonal structure of the verb. In section 5.3, we will turn to the tonal behaviour of the focus marker $a$ in more detail. It will be argued that the focus marker $a$ is lexically unspecified for tone, and that its surface tone 
systematically follows from its syntactic and phonological context. For the moment, suffice it to say that the surface tonal shape of $a$ is not fixed in Gùrùntùm. In some cases, $a$ carries a low tone, in others it carries a high tone.

The examples in (5) and (6) illustrate constituent focus on indirect objects and on locative adjuncts, respectively. Compare, once again, (6a) with focus on the locative gãa à shindi 'on the stone' with its neutral (all-new) counterpart without focus marker in (6b).

(5) Tí bà wúr má-ì à kwá?

3SG PROG bring water-DEF FOC who

'TO WHOM is he bringing the water?'

Tí bà wúr má-ì à báa-sì.

3SG PROG bring water-DEF FOC father-his

'He is bringing the water TO HIS FATHER.'

(6) a. Tí bà dáan-à yâu? Tí bà dáan-à gã́a shìndí. 3SG PROG sit-FOC where 3SG PROG sit-FOC head stone 'WHERE is he sitting?' 'He is sitting ON THE STONE.'

b.

Tí bà dàa gã̃ã shìndí. 3SG PROG sit head stone 'He is sitting on the stone.'

So far, we have restricted our attention to focus marking on nominal categories such as arguments and adjuncts. In section 3, we will see that focus marking is also possible on predicative expressions, such as VP and V, with one additional complication.

\subsection{Consistent focus marking across aspects/tenses}

Focus in Gùrùntùm is consistently marked across aspects and tenses by means of the focus marker $a$. Focus marking in the progressive aspect has already been illustrated in (3) to (6). (7a-c) illustrate morphological focus marking in the 
perfective aspect. In (7ab), focus is on the direct object. In (7c), focus is on the temporal adjunct. ${ }^{1}$ Again, $a$ cliticizes onto the immediately preceding verb.
a. Á kã̃a mài tí wúmì?
Tí wúm-à kwálingálá.
FOC what REL 3SG chew
3SG chew-FOC colanut 'WHAT did he chew?'
'He chewed COLANUT.'
b. Á kã̃ã mài tí vúní nvúrí? Tí vún-á lúurìn. FOC what REL 3SG wash yesterday 3SG wash-FOC clothes 'WHAT did she wash yesterday?' 'She washed CLOTHES.'
c. Tí vún lúurìn-ì vùr múkããa Tí vún-à nvúrí. 3SG wash clothes-DEF when 3SG wash-FOC yesterday 'WHEN did she wash the clothes?' 'She washed them YESTERDAY.'

Finally, (8ab) show focus marking in the future tense. In (8a), focus is on the direct object. In (8b), focus is on the subject. ${ }^{2}$

(8) a. Á kã̃a mài Àdàmú à pánì? Á máa mài Àdàmú à pánì. FOC whatREL Adamu FUTcarry FOC water REL Adamu FUT carry 'WHAT will Adamu carry?' 'Adamu will carry WATER.'

1 The temporal wh-pronoun vìr múkã ã 'when' represents an exception to the rule in that it is preceded by the $a$-marker.

2 We have found no evidence for focus marking in subjunctive clauses, e.g. in complements to intensional predicates, $\mathrm{cf}$. (i):

(i) Q: A kãa mai ti ba baa Hawwa ti pani?

FOC what REL 3SG PROG want Hawwa 3SG carry

'WHAT does he want Hawwa to carry?'

A: Ti baa Hawwa si ti pan maa.

3SG want Hawwa COMP 3SG carry water

'He wants Hawwa to carry WATER.'

Possibly, the absence of the $a$-marker has to do with a general impossibility of focus marking in intensional contexts. A similar situation obtains in Hausa, where (syntactic) focus marking is also blocked in subjunctive contexts (Tuller 1986). 

b. Á kwá à pân má-ì ? FOC who FUT carry water-DEF 'WHO will carry the water?'
Á Àdàmú à pân má-ì. FOC Adamu FUT carry water-DEF 'ADAMU will carry the water.'

\subsection{Realising focus in situ or ex situ}

In addition to the focus marker $a$, a non-subject constituent can be marked by realizing it ex situ in a left-peripheral position. More frequently, though, the focus constituent remains in its base position (in situ). Both options are also attested for inherently focused $w h$-expressions in wh-questions (see also Haruna 2003:126ff.). ${ }^{3}$

In (9a), the focused object is realised ex situ in the wh-question and in situ in the corresponding answer. In (9b), we have the same wh-question, but this time with the focused wh-expression in situ. ${ }^{4}$ The focus constituent in the corresponding answer is likewise in situ.
(9) a. Á kããa mài tí yáb ngwáí? Tí yáb-à dòoróo ngwáì. FOC whatREL 3SG sell out 3SG sell-FOC goat out 'WHAT did he sell?' 'He sold A GOAT.'

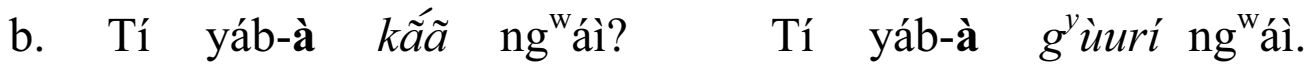 3SG sell-FOC what out 3SG sell-FOC millet out 'WHAT did he sell?' 'He sold (THE) MILLET.'

In (10), the focus constituent is realised ex situ both in the wh-question and in the corresponding answer:

3 Exceptions are the wh-expressions yàu 'where' and kómã́a 'how', which can only occur in their base position at the end of the clause (cf. Haruna 2003:130f.).

4 Other examples with in situ wh-expressions are found in (5), (6a), and (7c). 
(10) Á kãã mài tí náa wálì?

FOC whatREL 3SG catch farm

'WHAT did he catch on the farm?'

Á fúl mài tí náa wálì.

FOC COW REL 3SG catch farm

'It is a cow that he caught on the farm.'

The ex situ realization of non-subject foci employs a relative structure containing the relative marker mài (Jaggar 1988:181, Haruna 2003:121).

$$
\begin{aligned}
& \text { Tí tùu már mài wúr móláy-y-à. } \\
& \text { 3PL pay man REL bring fish-DEF-FOC } \\
& \text { 'They paid the man that brought the fish.' }
\end{aligned}
$$

The presence of relative syntax argues for a cleft-structure for the ex situ focusconstruction. Interestingly, the relative marker cannot occur with focused subjects, indicating that clefts are impossible with (focused) subjects in Gùrùntùm. ${ }^{5}$ In (12) (tones not marked) the relative marker mai is absent both in the $w h$-question and in the corresponding answer.
A kwa basi gobilish-i? FOC who read book-DEF 'WHO read the book?'
A Hafsa (*mai) basi gobilish-i. FOC Hafsa REL read book-DEF 'HAFSA read the book.'

It is worth pointing out that the absence of mai in (12) does not follow from a general impossibility of subject relativization, as witnessed by the subject relative clause in (13):

5 Parallel facts are reported for Margi (Hoffmann 1963). The reverse pattern is found in Hdi, where focused preverbal subjects are followed by a comment marker $t a$, whereas this marker is absent with all other fronted constituents (Frajzyngier 2002). 
(13) Gumar mai pan daabii ti ba maa bavuli.

boy REL carry basket 3SG PROG go market

'The boy that carried the basket is going to the market.'

Notice that the clefted constituent in ex situ constructions always has to be accompanied by the morphological focus marker $a$. In this respect, Gùrùntùm resembles intonation languages such as German or English, in which focus marking by means of accent can also, but need not be accompanied by clefting:

\section{(14) Context: What did Peter sell?}

a. He sold A CAT.

b. It was A CAT that he sold.

We conclude that the primary means of focus marking in Gùrùntùm is the morphological focus marker $a$. Concerning the motivation for clefting, this may have to do with pragmatic notions such as surprise, or the degree of (un)expectedness of a focus constituent in a particular discourse context: The more unexpected or surprising a focus constituent is in a particular context, the more likely is it to be realised ex situ. This explanation follows Hartmann and Zimmermann (t.a.), who argue that the ex situ realisation of focus constituents (or parts thereof) in Hausa, another West Chadic language, is best accounted for using the pragmatic notions of surprise or unexpectedness. ${ }^{6}$ The data in (15) suggest that this pragmatic explanation may be correct for Gùrùntùm, too. In an elicitation study, our informant was asked to provide spontaneous answers to wh-questions of the form What did Audu catch? Interestingly, he chose the in situ variant with domestic animals, such as dog and horse (cf. 15a). With rare wild animals such

6 That material which is more surprising, more important, or more relevant is marked in a special way is already coded in Gundel's (1988) First Things First Principle, Givón's (1988) principle Attend to the most urgent task first, or in Legendre's (2001) constraint Align Noteworthy. 
as crocodile and leopard, on the other hand, he chose the ex situ variant (cf. $15 b)$.

(15) a. Á kã́ã mài Audu náa?

FOC what REL Audu catch

'WHAT did Audu catch?'

Tí ná-a dùu/ dàa. in situ

3SG catch-FOC horse/ dog

'Audu caught A HORSE / DOG.'

b. Á kã̃a mài Áudù náa?

FOC what REL Audu catch

'WHAT did Audu catch?'

Á gàmshí/ gúù mài Áudù náa. ex situ FOC crocodile / leopard REL Audu catch

'Audu caught A CROCODILE / LEOPARD.'

Summing up, in addition to being marked by the focus marker $a$, non-subject foci can also be realised in a clefted structure. The obligatory presence of the morphological focus marker indicates the focus status of the constituent, whereas the trigger for clefting seems to be more pragmatic in nature and may have to do with the status of a non-subject focus constituent as surprising, noteworthy, or unexpected in a particular discourse situation.

\subsection{Summary}

The main observations of section 2 can be summarised as follows: First, constituent focus on arguments or adjuncts in Gùrùntùm is marked morphologically by a focus marker $a$, which precedes the focus constituent. Second, the focus marker $a$ occurs in all aspects. Third, focus constituents can occur in situ or ex situ (in a cleft-like structure). 


\section{Focus Ambiguity and Syntactic Restrictions on Focus Marking}

In this section, we consider how focus is marked on VP- or V-predicates and on parts of associative NPs. The central observation is that even though the morphological focus-marking system of Gùrùntùm allows for a lot of finegrained distinctions in the focus structure, the language is not free of focus ambiguities. In particular, predicate focus on VP or V and object (OBJ-) focus are marked alike by placing the focus marker before the object. Likewise, focus on subparts of an associative NP and focus on the entire NPs are marked alike by putting the focus marker before the associative NP. We argue that the two instances of focus-ambiguity in Gùrùntùm follow from syntactic restrictions on the placement of the focus marker $a$.

\subsection{Predicate Focus on V and VP}

Turning to predicate focus first, (16a-c) show that OBJ-, V-, and VP-focus are marked in identical fashion, resulting in focus ambiguity. Even though the focus constituent is the VP in (16a) and the main verb in (16b), the focus marker does not precede the verb (phrase) as we would expect given the generalization from section 2.1. Instead, the focus marker follows the verb and precedes the direct object. The resulting structures are ambiguous to sentences with constituent focus on the direct object, as in (16c).

(16) a. Á kãã mài tí bà pí? FOC what REL 3SG PROG do

'WHAT is he doing?'

Tí bà ròmb-á $\quad g^{w} e ́ i$. $V P$

3SG PROG gather-FOC seeds

'He is GATHERING THE SEEDS.' 
b. Á kãã mài tí bà pí náa $\mathrm{g}^{\mathrm{w} e ́ i ̀ ? ~}$

FOC what REL 3SG PROG do with seeds

'WHAT is he doing with the seeds?'

Tí bà ròmb-á $\mathrm{g}^{\mathrm{w} e ́ i ̀ . ~}$

3SG PROG gather-FOC seeds

'He is GATHERING the seeds.'

c. Á kã̃a mài tí bà rómbì?

FOC what REL 3SG PROG gather

'WHAT is he gathering?'

Tí bà ròmb-á g éì.

$O B J$

3SG PROG gather-FOC seeds

'He is gathering THE SEEDS.'

(17a-c) illustrate the same focus ambiguity with another example:

(17) a. Á kããa mài tí bà pí? FOC what REL 3SG PROG do

'WHAT is he doing?'

Tí bà wúm-á kwálíngálá. VP

3SG PROG chew-FOC colanut

'He is CHEWING (A) COLANUT.'

b. Á kã́ã mài tí bà pí náa kwálíngálá-ì?

FOC what REL 3SG PROG do to colanut-DEF

'WHAT is he doing with the colanut?'

Tí bà wúm-á kwálíngálá-ì.

3SG PROG chew-FOC colanut-DEF

'He is CHEWING the colanut.'

c. Á kã́ã mài tí bà wúmì?

FOC what REL 3SG PROG chew

'WHAT is he chewing?' 
Tí bà wúm-á kwálíngálá. $\quad O B J$

3SG PROG chew-FOC colanut

'He is chewing COLANUT.'

Interestingly, a parallel focus ambiguity between VP-, V-, and OBJ-focus is found in Tangale, a relatively close relative of Gùrùntùm from the West Chadic group, see Hartmann \& Zimmermann (2004).

The ambiguity between VP-focus and OBJ-focus is found in a wide variety of languages ${ }^{7}$ and can be accounted for in terms of focus projection from the focus-marked constituent, the object, to a focus constituent containing the focus exponent, the VP (see Selkirk 1984, 1995). The ambiguity between narrow focus on the verb and OBJ-focus, however, is a case that has - to the best of our knowledge - never been discussed in the literature. Nor is it accounted for by standard theories of focus (projection), such as Selkirk's (1984, 1995). The main question is why narrow focus on the verb should be marked on the following object, or alternatively why the focus marker cannot precede the verb in (16b) and (17b), as well as in the VP-focus cases in (16a) and (17a).

A potential solution, suggested by Büring (2006), is that the focus marker does indeed precede the verb or the VP at an earlier stage of the derivation. In the course of the derivation, the verb moves to a higher functional head F, leaving the focus marker behind in a position preceding the object. This potential derivation is sketched schematically in (18ab):

(18) a. underlying structure:

[FP SUBJ F a [vp V OBJ]]

b. surface structure:

[FP SUBJ $\quad \mathrm{V}+\mathrm{F}$ a $\left.\left[{ }_{\mathrm{vp}} \mathrm{t}_{\mathrm{V}} \mathrm{OBJ}\right]\right]$

7 See e.g. Selkirk $(1984,1995)$ for English, Uhmann (1991) for German, Schwarz (2005) for Kikuyu, and Eaton (2005) for the Khoisan language Sandawe. 
The structure in (18ab) is supported by the fact that such a process of verb movement to Infl has been proposed by Tuller (1992) for Tangale.

Tempting as the analysis in (18ab) may be, there are good arguments against it. First, verb movement to Infl in Tangale is argued to take place only in the perfective aspect because this is the only aspect without a preverbal aspectual marker. As a result, the verb has to move to Infl in order to enter into a checking relation with this functional head and pick up the required aspectual specification (Tuller 1992:311). In contrast, the Infl-position in (16) and (17) is lexically filled by the progressive auxiliary bà. Thus, if there was head movement of the verb in (16) and (17), leaving behind the focus marker as in (18), this movement would have to target a functional projection lower than Infl. We would need to stipulate this functional projection only for the sake of the movement account, somewhat reducing its appeal.

There is also a strong empirical argument against the movement account, which comes from the behaviour of sentences with narrow verb focus and a $3 \mathrm{sg}$ object pronoun. In Gùrùntùm, object pronouns are cliticized on the verb. Furthermore, 3sg object pronouns are covert, at least in the variant of Gùrùntùm that we investigated (see Haruna 2003 for variants in which 3sg object pronouns are overtly expressed). Interestingly, focus marking on the verb is absent with zero 3sg object pronouns, as shown in (19) and (20). Compare (19b) and (20b) with a full lexical object NP and the focus marker preceding the object NP, with (19a) and (20a), which contain a zero object pronoun and no focus marker:

(19) Context: What is he doing with the car?

a. Tí bà krí.

3SG PROG repair

'He is REPAIRING (it).' 
b. Tí bà kr-á dùsó-ì.

3SG PROG repair-FOC car-DEF

'He is REPAIRING the car.'
(20) a. Ti da wasar laam-i-a da, ti kuri. ${ }^{8}$ 3SG NEG fry meat- DEF-FOC NEG 3SG cook
'She did not fry the meat, she COOKED it.'
b. Ti da wasar laam-i-a da, ti kur-a laam-i. 3SG NEG fry meat-DEF-FOC NEG 3SG cook-FOC meat-DEF 'She did not fry the meat, she COOKED the meat.'

The empirical generalization seems to be that focused verbs without a following overt nominal object cannot be focus-marked by $a$. The movement account does not capture this generalization because it would predict the focus marker to follow the verb in (19a) and (20a), as it does in (19b) and (20b). ${ }^{9}$ Instead, we propose the following categorial restriction on focus marking in Gùrùntùm:

FocNom:

Focus Marking is licit only on nominal categories.

8 The preverbal negation marker in (20ab) appears to be not genuine to Gùrùntùm, but probably a structural borrowing from Hausa, in which negation is marked by the negative parenthesis $b a$... bá. As for the VP-final focus marker in the negated first clause in (20ab), as well as in ( $31 \mathrm{ab})$ below, it does not mark narrow focus on the verb. In sections 5 and 6 , it will emerge that the $a$-marker can also serve to focus on, or highlight bounded events as a whole when in sentence-final position. The $a$-marker appears to fulfill the same function in (20ab).

9 The absence of the focus marker in (19a) and (20a) does not follow from independent phonological reasons, as will emerge in sections 5.2.1 and 6. In principle, the $a$-marker can occur in sentence-final position, following the transitive verb and a zero object pronoun (see also fn. 8). Indeed, sentences such as (i) (example taken from Haruna 2003:78) are grammatical on a neutral interpretation (wide focus). Section 6 looks at sentence-final occurrences of $a$ in more detail.

(i) Tí yíl-à.

'He took (it) there.' 
(21) requires that the focus marker $a$ must precede an NP. Notice that a comparable bias for focus marking on non-verbal constituents is found in several other Chadic languages, see Hartmann \& Zimmermann (2004) for details. ${ }^{10}$ The restriction in (21) accounts for the absence of the focus marker in (19a) and (20a). Furthermore, it also accounts for the focus ambiguity between VP-, V-, and OBJ-focus with lexical object NPs, illustrated in (16) and (17). Because of (21), the focus marker $a$ must precede the object in transitive VPs no matter whether object, verb, or VP is in focus. ${ }^{11}$

\subsection{Associative NPs}

A second instance of focus ambiguity is found with complex associative NPs of the form $N_{1}$ of $N_{2}$. It shows that narrow focus on the $\mathrm{N}_{2}$-part and wider focus on the entire associative NP are marked in identical fashion: The focus-marker must precede the complex NP, no matter whether the complex expression $N_{1}$ of $N_{2}$ is focused (22-Q1), or just $N_{2}$ (22-Q2). Again, an analogous ambiguity is found in Tangale (Kenstowicz 1985).

(22) Q1: Á kã̃ã mài tí bà pí méerè?

FOC what REL 3SG PROG do theft

'WHAT is he stealing?'

Q2: Á [dòoré-i kwá] mài tí bà pí méerè? FOC goat-DEF who REL 3SG PROG do theft 'WHOSE goat is he stealing?'

${ }^{10}$ Observe that (21) is not violated by instances of focus marking on locative adverbials, such as gã̃a shindi 'on the stone' in (6a). As in other Chadic languages, Gùrùntùm has few prepositions proper: Locative and temporal relations are typically expressed by means of nominal expressions such as gãa a, which literally translates as 'head'. Consequently, the occurrence of the $a$-marker before the relational noun in locative adverbials is expected.

11 All by itself, (21) does not explain why the focus marker $a$ cannot occur before the subject NP with V- or VP-focus. Its obligatory occurrence before the object NP with V- and VPfocus follows from an additional locality principle, which requires a focus to be marked on, or as close as possible to the focus constituent, see Zimmermann (2006). 
A: Á [dòoré-i rèená] (mài tí bà pí méerè). FOC goat-DEF king (REL 3SG PROG do theft) 'He is stealing THE KING'S GOAT. / He is stealing THE KING'S goat.'

In view of the data in (22), we propose a second descriptive restriction on focus marking in Gùrùntùm in (23):

\section{FOCNP $_{\text {MAX }}$ :}

If the focus constituent is part of a complex NP, focus must be marked on the complex NP.

We can see at least two possible reasons for why (23) should hold, remaining neutral on which one is more adequate in the absence of further empirical evidence. First, it could be that the nominal parts of the associative NP are not NPs, but nominal heads. An N-N structure for structurally analogous associative NPs has been proposed for Bole by Schuh and Gimba (2004). If this is the right analysis for associative NPs, FoCNP $\mathrm{MAX}_{\mathrm{X}}$ in (23) would generalize to FocXP, which says that focus can only be marked on maximal projections. The assumption of FOCXP is motivated by the fact that there is no evidence for focus marking on sub-phrasal constituents, for instance on aspectual markers, in our corpus, nor is focus on subconstituents attested in other Chadic languages (see Hartmann \& Zimmermann t.a.).

Second, (23) could follow from prosodic requirements on focus marking. In particular, it could be a consequence of Truckenbrodt's prosodic constraint WRAP (Truckenbrodt 1999), which requires that lexical XPs not be 'split up' into several prosodic phrases. Assume for instance that the focus marker $a$ is placed at the prosodic boundary preceding the focus constituent in the normal case. Now, WraP says that if a maximal projection XP contains another maximal projection YP, both are mapped onto a single prosodic domain. In the case of associative NPs, this would mean that the smaller $\mathrm{NP}_{2}$ and the containing 
$\mathrm{NP}_{\max }$ are mapped onto a single prosodic phrase, which is then preceded by the focus marker. An immediate problem with this account arises in connection with VP-focus, as discussed in section 3.1. There, it was shown that the focus marker does not precede the VP, but the object NP, which is contained inside the VP. In other words, WRAP would be violated because the NP is not mapped onto a single prosodic phrase together with the containing VP. One way out of this dilemma is to assume that WRAP is a violable constraint that is outranked by FocNom in (21) in the case of VP-focus. We will take up the issue of violable constraints on focus marking in the next sub-section.

\subsection{On the interaction of IS-constraints and structural constraints in focus marking}

In the preceding two sub-sections, we have encountered two facts about the distribution of the Gùrùntùm focus marker $a$, which are surprising when seen from the perspective of European intonation languages. First, the focus marker $a$ does sometimes not precede the focus constituent. This happens with instances of V- and VP-focus. Second, the focus marker is sometimes completely absent. This happens with instances of narrow verb focus in the presence of a pronominalized (zero) object.

As a solution to these puzzles, we suggested that the distribution of the focus marker $a$ is subject to information-structural as well as syntactic constraints with sometimes conflicting requirements. A likely candidate for an information-structural constraint is Focus Prominence (FP, see e.g. Schwarzschild 1999, Büring 2001, Selkirk 2004), which is satisfied by the focus marker $a$ on the focus constituent in Gùrùntùm.

FP:

The focus constituent must be made prominent. 
In addition, there are the two syntactic constraints FocNom and FocNP $\mathrm{MAx}_{\mathrm{x}}$ (where FocNP $\mathrm{MAX}_{\mathrm{M}}$ is possibly a special instance of FocXP, or a derived effect of the more general prosodic constraint WRAP), which interact with FP in determining the position of the focus marker.

This is reminiscent of intonation languages where the placement of the focus-marking pitch accent is also subject to interacting, and sometimes conflicting information-structural, phonological, and syntactic constraints (cf. Büring 2001, Büring \& Gutiérrez-Bravo 2001). The main difference between Gùrùntùm on the one hand, and intonation languages like German (as explicated by Büring) on the other, is that the focus marker need not be located directly on the focused constituent in Gùrùntùm, but that it can shift to the following nominal constituent, e.g. with predicate focus. In extreme cases, focus marking may even be completely absent. This happens with narrow verb focus when there is no overt object NP to serve as the carrier of the focus marker $a$ in accordance with FocNom in (21). The cross-linguistic differences follow directly if we assume a different ranking of the IS-constraint FP and the structural constraints in the two languages. In intonation languages, the ISconstraint FP in (24) is undominated, hence never violated (Schwarzschild 1999, Büring 2001), and outranks all structural constraints governing the placement of the pitch accent. As a result, a focus constituent is always marked prosodically by means of a pitch accent somewhere on the constituent. In Gùrùntùm, on the other hand, it is the structural constraint FocNom in (21), which is undominated, hence outranking the IS-constraint FP (and possibly other structural constraints, such as WRAP, see the end of the preceding sub-section). The cross-linguistic differences in ranking are illustrated schematically in (25):

(25) a. Ranking in Gùrùntùm:

FOCNOM $>$ (WRAP) $>$ FP

b. Ranking in intonation languages: $F P>>\ldots$ structural constraints 
Summing up, the dislocation or absence of the focus marker $a$ in Gùrùntùm follows from the fact that structural constraints outrank the IS-constraint FP, which requires that focus must be marked on the focus constituent. ${ }^{12}$

\section{Focus Marking and Focus Types}

This section discusses the grammatical realisation of various focus types, as introduced in section 1. It is shown that the focus marker $a$ marks all types of constituent focus, such as new information focus, selective focus, corrective focus, and contrastive focus. Furthermore, $a$ occurs in predicative constructions. In sum, Gùrùntùm provides evidence for a uniform category of constituent focus that is unanimously marked by the focus marker $a$. Moreover, the discussion shows that there is no 1:1-correlation between a specific focus type and its syntactic realisation as ex situ or in situ. Instead, most focus types can be realised either ex situ or in situ, depending on the pragmatic objectives of the speaker (see section 2.3 above). Finally, we will turn to instances of presentational focus, showing that these also involve an $a$-marker, but that they differ from the other focus types in another respect.

\subsection{New information focus}

As shown in section 2.3, new-information foci can be realised either in situ or ex situ, as long as they are preceded by the focus marker $a$. (26ab) are repeated from (15ab) for convenience:

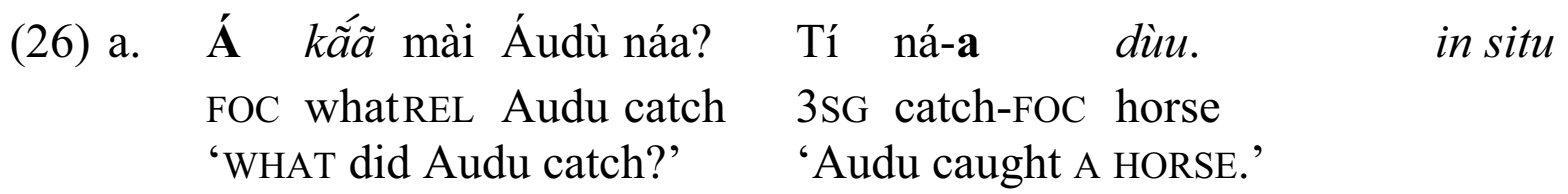

12 In practice, the matter is of course more complicated than sketched here. See Zimmermann (2006) for a more articulate OT-style analysis of focus marking in West Chadic. 

b. Á kãã mài Áudù náa? Á gàmshí mài Áudù náa. ex situ FOC whatREL Audu catch FOC crocodile REL Audu catch 'WHAT did Audu catch?' 'Audu caught A CROCODILE.'

\subsection{Selective focus}

Instances of selective focus, which are used to choose from an explicitly given list of alternatives, are likewise preceded by the focus marker $a$. Again, the focus constituent is realised either in situ (cf. 27) or ex situ (cf. 28):

Nvúrí á kã́ã mài Mài Dáwà shí? Yáà kóo á mólán?
yesterday FOC what REL Mai Dawa eat chicken or FOC fish
'Yesterday, WHAT did Mai Dawa eat? CHICKEN or FISH?'

Nvúrí Mài Dáwà sh-á yáà, bà á mólán dà. in situ yesterday Mai Dawa eat-FOC chicken, NEG FOC fish NEG 'Yesterday Mai Dawa ate CHICKEN, not FISH.'

(28)

Mài Dáwà bà sh-á yáà kóo á móláy?
Mai Dawa PROG eat-FOC chicken or FOC fish
'Is Mai Dawa eating CHICKEN or FISH?'

Á yáà mài Mài Dáwà bà shí. ex situ FOC chicken REL Mai Dawa PROG eat 'Mai Dawa is eating CHICKEN.'

\subsection{Corrective focus}

Instances of corrective focus, which are used to correct a previous speaker's statement, are also preceded by the focus marker $a$. Again, the focus constituent is realised either in situ (cf. 29) or ex situ (cf. 30): ${ }^{13}$

13 As already mentioned in fn. 8, the VP- or sentence-final occurrence of the focus marker in (29A) and (30A) does not indicate narrow focus, but rather seems to focus on the perfective event as a whole. See sections 5.2.1 and 6 for more discussion. 
(29) A: Músá yâb fúl-à nvùrì.

Musa buy cow-FOC yesterday

'Yesterday, Musa bought a cow.'

B: Áà, tí yáb-à mbóorò, bà á fúl dá. in situ no 3SG buy-FOC sheep NEG(Ha.) FOC cow NEG

'No, he bought A SHEEP, not A COW.'

(30) A: Hàwwá pân yánsí ìsh-à.

Hawwa carry wood fire-FOC

'Hawwa carried fire wood.'

B: Áà, bà á yáysí ishí mài tí pân dà,...

no NEG(Ha.) FOC wood fire REL 3SG carry NEG, ...

'No, it is not FIREWOOD that she carried, ...

... á máa mài tí pánì.

ex situ

... FOC water REL 3SG carry.

... it is WATER that she carried.'

\subsection{Contrastive focus}

Instances of contrastive focus, in which two elements of the same syntactic category and semantic word field are juxtaposed, are likewise preceded by the focus marker $a$ :

(31) Ti da yab ful-a da, ti yab-a duu.

3SG NEG buy cow-FOC NEG 3SG buy-FOC horse

'He did not buy a cow, he bought A HORSE.' 


\subsection{Predicative constructions}

The focus marker $a$ also shows up in verbless predicative constructions, in which it precedes the predicate: ${ }^{14}$

(32) a. Bíin-ì á gàarì. house-DEF FOC old 'The house is OLD.' b. Mbáldà-í á gí mbàlí. lion-DEF FOC of red 'The lion is RED.'

The occurrence of $a$ in these contexts is not unexpected given that - in the unmarked case - the predicate in predicative constructions constitutes a new-information focus. After all, the predicate specifies a hitherto unknown property of a known entity, the topic. In Gùrùntùm, then, the focus status of the predicate is consistently marked by $a$. See also Green (2004) for a parallel claim that the particle nee/cee in Hausa predicative constructions indicates focus on the predicate.

Summing up so far, Gùrùntùm provides ample evidence for a uniform category of constituent focus: All types of constituent focus are marked alike by means of the focus marker $a$. The next subsection deals with a slightly different type of focus, namely with presentational focus in all-new sentences, which is marked in a slightly different way.

\subsection{Presentational focus}

Presentational focus is found with all-new utterances that depict a temporally or spacially bounded scene or situation. In Gùrùntùm, presentational constructions also feature an $a$-marker:

14 Predicates in Gùrùntùm cannot only be nominal, but also adjectival, such as gàarì 'old' in (32a). The occurrence of the focus marker $a$ before adjectives is captured by the categorical constraints FocNP in (21) on the common assumption that adjectives have the feature specification $[+\mathrm{N},+\mathrm{V}]$. 

Zí gí mài tí wáani dà tí vùl bà wùun-à. PL of REL 3PL healthy NEG 3PL many place medicine-FOC 'There are many patients in the hospital.' (lit.: Those that are not healthy, they are many in the hospital.) (wùunu 'medicine')

These instances of presentational focus differ in two respects from the other kinds of focus that we have seen so far. First, the $a$-marker does not precede the focus constituent, but it occurs in sentence-final position. Second, presentational constructions do not involve narrow focus on a single constituent, but rather wide focus over the entire clause. Below in section 6 , we will argue that the two properties are related. We will further argue that the $a$-marker has a double function as a foregrounding device: At the sentential level, it serves to mark the focus constituent, which it precedes. At the supra-sentential level of discourse structure, on the other hand, it follows on all-new clauses and marks these as foregrounded, more prominent, or more relevant relative to other parts of the discourse, in the sense of Hopper (1979).

\section{On a's Double Role as a Marker of Focus and Perfectivity}

Before turning to the $a$-marker's double role as a foregrounding device in section 6 , it is necessary to look at another purported function of the $a$-marker. Jaggar (1988) and Haruna (2003) treat $a$ in perfective clauses as a perfectivity marker. Opposing this view, we argue that $a$ never functions as a perfectivity marker, but always as a foregrounding or focusing device. The observed affinity between (sentence-final) $a$-marking and perfectivity will then follow from a general affinity between foregrounding and perfectivity, as discussed in Hopper (1979). Section 5.1 sketches Jaggar's and Haruna's analysis of $a$ as a perfectivity marker. In section 5.2, we present syntactic and semantic evidence in favour of our analysis of $a$ as a focus marker in perfective contexts as well. The section 
concludes with an aside on the tonal shape of the focus marker $a$, which depends on the phonological context. In particular, $a$ is not always low-toned when it occurs in perfective clauses, contradicting claims in Jaggar (1988) and Haruna (2003).

\section{1 $A$ as a perfectivity marker}

Jaggar (1988) and Haruna (2003) argue that perfective aspect is marked by a low-toned suffix -à in Gùrùntùm. Consequently, they would analyse the $a$-suffix in the perfective examples in (7) and (9) above as a perfectivity marker, rather than as a focus marker. The paradigm in (34) shows that $a$ would be peculiar as an aspectual marker in that it would be the only one that is suffixed to the verb (Haruna 2003:86), see (34d). In contrast, the markers of progressive (bà), future $(\dot{a})$ and habitual ( $(\dot{a} d i)$ aspect, respectively, all precede the verb (cf. (34a-c)):

(34) a. Tí bà wùmì. 'He is chewing.'

b. Tá á wùmì. 'He will chew.'

(tá $<t i ́$ before $a ́$, see Haruna 2003:84)

c. Tá á dí wùmì. 'He usually chews.'

d. Tí wúm-à. 'He chewed.'

A second peculiar property of the purported perfectivity marker $a$ is that it can be suffixed 'either to the verb stem or to a VP-final constituent' (Haruna 2003:86, see also Jaggar 1988). The different possibilities for the distribution of $a$ in perfective contexts according to Haruna and Jaggar are schematized in (35):

(35) a. SUBJ [VP V-a (OBJ) ]

b. SUBJ [VP V OBJ-a ]

c. SUBJ [VP V ADJ-a ] 
In the following, we provide evidence against this analysis of the $a$-marker in perfective clauses. Rather, we argue that $a$ is a focus marker in perfective contexts, too.

\section{2 $A$ as a focus marker in perfective contexts}

There are two kinds of evidence, syntactic and semantic, against the analysis of $a$ as a perfectivity marker, and for the analysis of $a$ as a focus marker in perfective contexts.

\subsubsection{Syntactic evidence}

A closer look at $a$ in perfective clauses shows that its syntactic distribution depends directly on information-structure, namely on focus. The $a$-marker must precede the focus constituent in the perfective, as it does in all other aspects. In (36a) and (37a), a precedes the focused direct object, cliticizing onto the preceding verb. This corresponds to the configuration in (35a). In (36b) and (37b), in contrast, $a$ precedes a focused locative phrase and (optionally) cliticizes onto the preceding direct object.

$\begin{array}{lll}\text { (36) a. } & \text { Á kã̃a mài tí vúní nvùrì? } & \text { Tí vún-á lúurìn. } \\ \text { FOC what REL 3SG wash yesterday } & \text { 3SG wash-FOC clothes } \\ \text { 'WHAT did she wash yesterday?' } & \text { 'She washed CLOTHES.' }\end{array}$

b. Tí vún lúurìn-í-à yáù?

3SG wash clothes-DEF-FOC where

'WHERE did she wash the clothes?'

Tí vún lúurìn-í-à biì .

3SG wash clothes-DEF-FOC home

'She washed the clothes AT HOME.'

(37) a. Á kãã mài tí pánì â díngà-i? FOC what REL 3SG take from shelf-DEF 'WHAT did he take from the shelf?' 
Tí pán-à súurí â díngà-i.

3SG take-FOC knife from shelf-DEF

'He took A KNIFE from the shelf.'

b. Tí pân súurí à yâu?

3SG take knife FOC where

'WHERE did he take the knife from?'

Tí pân súurí-à gã̃a díngà.

3SG take knife-FOC on shelf

'He took the knife FROM THE SHELF.'

The analysis of $a$ as an aspectual marker of perfectivity has nothing to say about the different placement of $a$ in the a- and b-sentences. The analysis of $a$ as a focus marker, on the other hand, directly accounts for these distributional differences.

An even stronger argument for the analysis as a focus marker comes from the behaviour of perfective clauses with subject focus in (38). It shows that, whenever the subject is focused, $a$ appears sentence-initially and not as a suffix on $V$ or $V P$. That is, in perfective sentences with subject focus there is no $a$ suffix on verb or VP at all.

(38) a. Á kwá wûm kwálíngálá-ì? Á rèená wûm kwálíngálá-ì. FOC who chew colanut-DEF FOC king chew colanut-DEF 'WHO chewed the colanut?' 'THE KING chewed the colanut.'

b. Á kwá ròmbí géì? Á zi bó ròmbí géì. FOC who gather seeds FOC PL child gather seed 'WHO gathered the seeds?' 'THE CHILDREN gathered the seeds.' 
Again, the analysis of $a$ as an aspectual marker cannot account for the absence of an $a$-suffix in perfective clauses with subject focus, whereas it follows directly on the analysis of $a$ as a focus marker. ${ }^{15}$

A final observation concerning the distribution of $a$ in perfective clauses is that sentence-final occurrences of $a$ are restricted to instances of all-new or sentential focus.

(39) a. Tí vún lúurìn nvùrì-à.

all-new

3SG wash clothes yesterday-FOC

'She washed clothes yesterday.'

b. Tí pân súurí gã̃ã díngà-à. all-new

3SG took knife on dinga-FOC

'He took the knife from the shelf.'

c. Tí náa fúul à wál-à / à gãã nvúrí-à.

all-new

3SG catch cow at farm-FOC / at head day-FOC

'He caught a cow at the farm / in the morning.'

d. Tí yâb g ${ }^{\mathrm{y}}$ ùurí $\mathrm{ng}^{\mathrm{w}}$ ái-à.

all-new

3SG sell millet out-FOC

'He sold the millet.'

The situation is entirely parallel to that found with the all-new presentational focus constructions in (33) in section 4.6. In section 6, we will therefore argue that the sentence-final as in (39) are likewise focus markers attached to the

15 Interestingly, Jaggar (1988:181) cites an example of the same form as (38ab). In (i), there is no $a$-suffix in the presence of subject focus. Instead, the $a$-marker precedes the focused subject:

(i) Q: $\mathrm{A} \quad \mathrm{k}^{\mathrm{w}}$ aa pan ndanshi bàn gìdi? FOC who carry hoe into room 'WHO (sg.) carried the hoe in the room?'
A: A bà-sì pan-di. FOC father-his carried-it 'HIS FATHER carried it (in).' 
predicate or the clause, which serve to foreground a bounded event denoted by the perfective clause in the sense of Hopper (1979). ${ }^{16}$

\subsubsection{Semantic evidence}

The semantic evidence for analysing $a$ as a focus marker also in the perfective aspect comes from the interpretation of perfective sentences containing adverbial quantifiers, such as always or usually, the interpretation of which is known to be sensitive to the focus/background structure of a clause (see Lewis 1975, Rooth 1985, 1992, Partee 1991, von Fintel 1994, Herburger 2000 among many others). We show that the position of the $a$-marker affects the truthconditions of clauses with adverbial quantifiers in Gùrùntùm in line with what semantic theories would predict if $a$ were indeed a focus marker.

The sentences in (40) illustrate the focus sensitivity of adverbial quantifiers for English:

(40) a. John always ate RICE $\mathrm{FOC}$.

'Always, if John ate something, he ate RICE.'

b. JOHN $\mathrm{FOC}$ always ate rice.

'Always, if somebody ate rice, it was JOHN.'

c. [John always ate RICE $]_{\mathrm{FOC}}$.

'Always, in a given (contextually-specified) situation, John ate rice.'

The empirical generalization is that the focused material, which is marked by a nuclear accent, must not occur in the restrictor, but in the nuclear scope of the adverbial quantifier.

The sentences in (41) show that a different position of $a$ in perfective clauses has an analogous effect on the interpretation of adverbial quantifiers in

\footnotetext{
16 See also the notions of predication focus / event focus in Wolff (2003).
} 
Gùrùntùm. ${ }^{17}$ In (41a), $a$ precedes the direct object and the latter is interpreted in the nuclear scope of the adverbial quantifier, as witnessed by the consultant's comment in brackets. In (41b), $a$ precedes the subject, and the subject is interpreted in the nuclear scope of the quantifier. Finally, in (41c), $a$ attaches to a full (core) sentence, tí shí gànyáhúà, which is consequently mapped onto the nuclear scope in its entirety.

(41)a. Kóo vùr mókẫã Mài Dáwà sh-á gànyáhú.

$O B J$ every when Mai Dawa eat-FOC rice 'Always Mai Dawa used to eat RICE. ("this is about what Mai Dawa ate")' = Always, if Mai Dawa ate something, it was rice.

b. Kóo vùr mókã̃ã á Mài Dáwà shí gànyáhú. SUBJ every when FOC Mai Dawa eat rice 'It is only MAI DAWA that always used to eat rice.' $=$ Always, if somebody ate rice, it was Mai Dawa.

c. Kóo vùr-mókã̃ã Mài Dáwà sái tí shí gànyáhú-à.

Clause every when Mai Dawa then 3SG eat rice-FOC 'Always, Mai Dawa used to eat RICE.' = Always, in a given (contextually-specified) situation, Mai Dawa ate rice.'

The perfective clauses in (41) show that all instances of $a$, including sentence-final $a$, behave alike: The syntactic position of $a$ has an effect on the semantic interpretation. The a-marked constituent is interpreted in the nuclear scope of the adverbial quantifier. Given the parallel facts observed for English, the differences in interpretation between (41a-c) will follow directly if $a$ is treated as a focus marker.

Summing up, the preceding two sub-sections have shown that the distribution of $a$ in perfective clauses and its interpretive effects follow from

17 The first line of the paraphrases cites the paraphrase/translation provided by our native speaker. 
focus structure. Based on this, we therefore conclude that $a$ is a focus marker in perfective clauses, too. A further consequence of our reanalysis is that perfectivity in Gùrùntùm is not marked by a perfective suffix. Rather, it is marked by zero marking, i.e. by the absence of an overt aspectual marker, which is accompanied by a tonal change in the stem vowel of the verb from $\mathrm{L}$ to $\mathrm{H}$ with certain verb classes (Haruna 2003: 77). From a cross-linguistic perspective, the marking of perfectivity by the absence of any overt morphological marking is not restricted to Gùrùntùm. See e.g. Hyman et al. (2002) on zero perfective marking in Leggbó. Finally, we would like to contend that the affinity of focus marking on sentences to perfectivity or completeness observed in Gùrùntùm (cf. $39 \mathrm{a}-\mathrm{d}$ ), is not uncommon in the languages of the world, and may well reflect a universal tendency, see Hopper (1979). We will return to this point in section 6.

\subsection{Tonal properties of $a$}

Before going on, we turn to the tonal properties of $a$ in perfective clauses. Even though a comprehensive study of the prosodic system of Gùrùntùm is still lacking, the evidence concerning the tonal shape of $a$ is sufficiently robust to warrant a few conclusions. In particular, we show that $a$ does not always carry low tone when it appears on V or VP in perfective clauses, contrary to claims in Jaggar (1988) and Haruna (2003). This shows at least that there is no low-toned perfective suffix $-\grave{a}$. The varying tones on $a$ do not argue against an analysis as an aspectual marker per se. However, the $a$-marker in perfective clauses resembles the focus marker $a$ in other contexts in that both have no fixed tonal appearance. Given this similarity in tonal behaviour, the varying tonal shape of $a$ constitutes indirect phonological evidence for the analysis of $a$ as a focus marker in perfective contexts, too.

The relevant generalisations concerning the tonal appearance of $\grave{a}$ in perfective clauses can be summarised as follows. First, with HH verbs such as 
vúni 'wash', and LH verbs such as ròmbi 'gather', a carries $\mathrm{H}$ tone if a complement follows the verb.

(42) a. Tí vún-á lúurìn. 3SG wash-FOC clothes 'He washed CLOTHES.'

b. Tí ròmb-á géè. 3SG gather-FOC seeds 'He gathered SEEDS.'

Second, with monosyllabic H verbs, such as shi 'eat', $a$ also carries $\mathrm{H}$ tone.

$$
\begin{array}{llllll}
\text { Nvúrí } & \text { Mài Dáwà sh-á } & \text { yáà, bà } & \text { á móláy } & \text { dà. } \\
\text { yesterday } & \text { Mai Dawa eat-FOC chicken, NEG(Ha.) } & \text { FOC fish } & \text { NEG } \\
\text { 'Yesterday } & \text { Mai Dawa ate CHICKEN, not FISH.' }
\end{array}
$$

Third, $a$ carries L tone with HL verbs, such as wúmì 'chew' or yábì 'sell'.

$$
\begin{aligned}
& \text { (44) Tí wúm-à kwálíngálá. } \\
& \text { 3SG chew-FOC colanut } \\
& \text { 'He chewed COLANUT.' }
\end{aligned}
$$

Fourth, $a$ always carries L tone when it occurs at the right edge of VP, i.e. when it occurs on verbs without overt complements, or when it occurs on the last constituent within the VP:
(45) a. Tí vún lúurìn-í-à $]_{\mathrm{VP}}$ bíin
$(=(36 b))$
3SG wash clothes-DEF-FOC house
'She washed the clothes AT HOME.'
b. Tí yâb g $\mathrm{g}^{\mathrm{y}}$ ùurí $\mathrm{ng}^{\mathrm{w}}$ ái-à̀ $]_{\mathrm{VP}}$.
3SG sell millet out-FOC
'He sold the millet.'


Based on evidence from other West Chadic languages ${ }^{18}$, we tentatively assume that the right edge of VP constitutes a prosodic phrase boundary in Gùrùntùm, thus separating the VP from any optional locative or temporal adjuncts.

Finally, in phrase-initial position, $a$ carries $\mathrm{H}$ tone before focused non-wh NPs (46a). In contrast, $a$ 's tonal realization (although still quite high) is not as high as that of following wh-expressions, which are always realized at a very high pitch level. There are at least two possible phonological explanations for this. Either $a$ carries an initial boundary tone $\mathrm{H} \%$, which is phonetically realized lower than the ideophonic extra high tone of the $w h$-expression. Or $a$ carries no phonological tone whatsoever, and its medium to high phonetic realization follows from its integration into the general intonational contour on the way to the extra high tone. In the absence of the required data for an evaluation of these possibilities, we mark all phrase-initial occurrences of $a$ with H tone (46b).

(46) a. $\Phi\left[\right.$ á $\left.\mathrm{NP}_{\mathrm{FOC}}\right]$

b. $\quad \Phi\left[\right.$ á $\left.w h_{\mathrm{FOC}}\right]$

Setting aside phrase-initial occurrences of $a$, the different tonal realization of the $a$-marker in non-initial position seems to follow from a number of general prosodic processes that are operative in the language. First, the focus marker $a$ does not carry inherent lexical tone. Second, in VP-final or sentence-final position (cf. (45)), an L\%-boundary tone (Pierrehumbert 1980, Beckman \& Pierrehumbert 1986) associates with the toneless focus marker $a$, as illustrated in (47):

$$
\begin{aligned}
& {[\ldots-\grave{a}]_{\Phi}} \\
& \mathrm{L} \%
\end{aligned}
$$

Third, if $a$ cliticizes onto the verb and is not located in phrase-final position, it associates with the tone of the final vowel of the verb, which it replaces after

18 See e.g. Tuller (1992:312) for Tangale and Maina Gimba (2000:19) for Bole. 
vowel elision. This is illustrated schematically in (48) for four different tonal patterns. Recall from section 2.1 that the final vowel of the verb is elided before a following object, while the tone of the vowel is preserved.

\begin{tabular}{|c|c|c|c|c|c|}
\hline ) a. & $\begin{array}{l}\text { shí } \\
\qquad \mathrm{H}\end{array}$ & $+\mathrm{a}$ & $\rightarrow$ & $\begin{array}{c}\text { shá } \\
\text { H }\end{array}$ & 'eat' \\
\hline b. & $\begin{array}{c}\text { ròmbí } \\
\mathrm{L} H\end{array}$ & $+\mathrm{a}$ & $\rightarrow$ & $\begin{array}{l}\text { ròmbá } \\
\mathrm{L} \quad \mathrm{H}\end{array}$ & 'gather' \\
\hline c. & $\begin{array}{l}\text { vúní } \\
\text { H H }\end{array}$ & $+\mathrm{a}$ & $\rightarrow$ & $\begin{array}{l}\text { vúná } \\
\mathrm{H} \quad \mathrm{H}\end{array}$ & 'wash' \\
\hline d. & $\begin{array}{l}\text { wúmì } \\
\text { H L }\end{array}$ & $+\mathrm{a}$ & & $\begin{array}{l}\text { wúmà } \\
\mathrm{H} \quad \mathrm{L}\end{array}$ & 'chew' \\
\hline
\end{tabular}

That tone is indeed preserved under vowel elision can be seen from forms such as wûm in (38a) and pân and yâb in (39bd), respectively, where the $\mathrm{H}$ tone on the remaining vowel combines with the L-tone of the elided vowel to form a falling HL-sequence.

Summing up, although many questions remain, we have shown that the tone of the $a$-marker in perfective contexts is not constant, but varies depending on its tonal context. Since the focus marker $a$ also varies in tone, we take this as additional evidence in favour of our analysis of $a$ as a focus marker in all aspects, including the perfective.

\section{Sentence Final $a$ as a Foregrounding Device}

Let us finally turn to the remaining puzzle concerning the nature of sentencefinal $a$ in presentational constructions (see section 4.6) and in perfective clauses (see section 5.2.1). The puzzle is presented in section 6.1. After a brief look at a number of parallel facts in Malay in section 6.2, we will propose an analysis of 
the sentence-final $a$ in section 6.3. In particular, we argue that sentence-final $a$ functions as a foregrounding device at the discourse level, in the sense of Hopper (1979).

\subsection{The puzzle}

At the end of section 5.2.1, it was shown in connection with (39ab), repeated as (49), that all-new sentences in the perfective aspect are explicitly marked by the focus marker $a$ in sentence-final position.

(49) a. Tí vún lúurìn nvùrì-à.

3SG wash clothes yesterday-FOC

'She washed clothes yesterday.'

b. Tí pân súurí gã̃ã díngà-à.

3SG took knife on dinga-FOC

'He took the knife from the shelf.'

Notwithstanding the unusual position of the $a$-marker, which precedes the focus constituent in all other contexts, its presence in (49) seems to owe to the fact that the entire sentence is in focus. Somewhat surprisingly, though, all-new sentences are unmarked in all other aspects, for instance in the progressive (50a), the future (50b) and the habitual (50c).

(50) a. Tí bà nyóolì góobílìshí.

3SG PROG write letter

'He is writing a letter.'

b. Tá-a má íyà táu-gàná gáb.

(Haruna 2003:91)

3SG-FUT go after moment small

'She will go after a short while.'

c. Tá-a dì wárí.

(Haruna 2003:89)

3SG HAB come

'She usually comes.' 
The picture becomes even more complicated if we look at presentational sentences again, which also occur with a sentence-final $a$, see (51ab) (and section 4.6). If the $a$-marker appears in a non-final position (cf. (51c)), or if it is absent altogether (cf. (51d)), presentational sentences are ungrammatical.

(51) a. Zí dùusó vùl gã̃ã $n^{y}$ úngsù kwàr-à.

PL car many on street today-FOC

'There are many cars on the road today.'

b. Kwàrì zí dùusó vùl gã̃ã $\mathrm{n}^{\mathrm{y}}$ úngsù-à. today PL car many on street-FOC 'There are many cars on the road today.'

c. * Kwar-a zi duuso vul gã $n^{\mathrm{y}}$ ungsu.

d. * Kwari zi duuso vul gã $\mathrm{n}^{\mathrm{y}}$ ungsu.

The puzzle can be summarized as follows: Why would the marking of sentence focus be restricted to perfective and presentational sentences? Before we will propose a tentative solution to this question, we present some facts from Malay, which features a morphological focus marker that resembles the $a$-marker in Gùrùntùm in an intriguing way.

\subsection{Focus and foregrounding in Malay}

Malay has a morpheme lah, which is traditionally described as a marker for focus and perfectivity. In his extremely insightful article, Hopper (1979) derives the at first sight mysterious connection between focus and perfectivity from a unified analysis of lah as a foreground marking device. In this section, we present Hopper's analysis in some detail, as it will lay the ground for our analysis of the $a$-marker in Gùrùntùm. 
First, the particle lah is used for marking ex situ focus constituents, see (52) (Hopper's example (1)) where fronting of the focused direct object gives rise to a relative construction.

$$
\begin{aligned}
& \text { Anjing-lah yang hilang, bukan kuching. } \\
& \text { dog-PRT which lost NEG cat } \\
& \text { 'It was a dog I lost, not a cat.' }
\end{aligned}
$$

Secondly, the particle lah appears suffixed to the verb in perfective sentences, which has led grammarians to the assumption that lah is an aspectual marker of perfectivity.

$$
\begin{aligned}
& \text { Pergi-lah ia. } \\
& \text { go } 3 \mathrm{sG} \\
& \text { 'He went.' }
\end{aligned}
$$

The basic insight of Hopper (1979) is that these two apparently unrelated functions of lah are different reflexes of one and the same phenomenon, that is foregrounding. A foregrounded constituent is informationally more prominent in relation to other ones in the background. A major instantiation of foregrounding is, of course, focus. Given this, it is not surprising that lah appears after fronted focus constituents, such as in (52).

The presence of lah on the verb in the perfective sentence (53) is due to the fact that the whole event is foregrounded. The central relation between foregrounding and perfectivity follows from a universal implicational relation: In order for an event to be foregrounded, it must be bounded or completed. Second, a typical (though not the only) way of presenting an event as bounded or completed is to present it as anterior to subsequent events. Finally, anteriority is typically expressed through perfectivity. Ongoing or overlapping events are unsuitable for foregrounding (Hopper 1979:39,47). Thus, since lah functions as 
a focus or foregrounding marker, it only appears in sentences which denote completed events. This is illustrated in the following example from Hopper (1979:48).

(54) a. Maka apabila masok-lah kedalam hutan, maka bertemu dengan a Jakun.

'And when they entered the forest, they met a Jakun.'

b. Maka apabila ia melihat orang datang, maka lari-lah ia masok hutan.

'And when he saw the men coming, he ran into the forest.

In (54a), it is evident that entering the forest is completed before the meeting of the Jakun takes place. The two events do not overlap. Consequently, the first verb can be followed by lah. No such connotation of anteriority is present in the temporal when-clause in (54b) where the events denoted by main and subordinate clause are construed as simultaneous or overlapping, see Hopper (1979:48), and where lah is absent.

It should be clear by now why lah is traditionally assigned the function of a perfectivity marker: Being foregrounded, the events it marks must be bounded or completed, and completion is usually associated with the perfective aspect. To sum up, the morpheme lah operates at the discourse level where it marks focused or foregrounded constituents. As Hopper says: "These two functions foregrounding and focusing - are not separable, but are aspects of one and the same principle" (p. 47).

\subsection{Foregrounding in Gùrùntùm}

We propose that the final $a$ marker in Gùrùntùm works the same way as Malay lah: The function of sentence-final $a$ is to foreground the sentence as a whole, just like sentence-internal $a$ serves to foreground narrowly focused constituents. For this reason, event or sentence focus marking in Gùrùntùm is restricted to the 
two proto-typical constructions that present situations or events as completed and whole entities: presentational constructions and constructions in the perfective or completive aspect (see also Comrie 1976:18). Hopper's universal implicational relation between foregrounding and perfectivity therefore also holds in Gùrùntùm: The foregrounding marker $a$ is incompatible with progressive, future and habitual sentences, which do not denote completed events, explaining its absence in (50a-c).

The analysis of sentences with final $a$ as foregrounded structures is supported by the following observations. First, the analysis implies that sentence focus will not be automatically marked in Gùrùntùm, not even in the perfective aspect (see below), but only if the sentence denotes a foregrounded event. Because of this, sentence-final $a$ is not obligatory in sentences with perfective interpretation, cf. in narrative sequences such as (55) from Haruna (2003:139) (our glosses):

$$
\begin{aligned}
& \text { Zi mùuzìi kàram ba pàn yansi, ti } y u \text { wùshù bàn yaahu, } \\
& \text { PL woman go PROG carry wood 3PL see snake in grass } \\
& \text { tì pàn yaysi tì } \mathrm{g}^{\mathrm{y}} \mathrm{u} \text { da. } \\
& \text { 3PL carry wood 3PL kill ?? } \\
& \text { 'The women went to carry firewood and they saw a snake in the grass } \\
& \text { and they took a firewood and killed it.' }
\end{aligned}
$$

According to Haruna (op. cit., our italics), the sequential construction "imparts unity to the actions depicted, and conversely, it enables these actions to be described without giving them unwanted prominence." In other words, the events denoted in (55) are presented as parts of a complex event. As such, the

19 Unfortunately, Haruna provides no interlinear glosses, but only the paraphrase given. As far as we know, and as shown in (20), the sentence-final marker $d a$ is the negative marker. So, perhaps the final clause in (55) should better translate as '...but they didn't kill it.' 
individual events are not foregrounded and, although interpreted as perfective, are not marked by final $a$.

Secondly, final $a$ can occur on the last of a series of sentences that combine to form a bigger event. In (56), final $a$ occurs on the final clause, which denotes the main event in the sequence.

$$
\begin{aligned}
& \text { Kado ma sai ti karmi bavuli. Ti kadi ti mai gãa yuys-a. } \\
& 3 \mathrm{SG} \text { too then } 3 \mathrm{SG} \text { go market } 3 \mathrm{SG} \text { return } 3 \mathrm{SG} \text { err on way-FOC } \\
& \text { 'She too, she went to(wards) the market, she returned, she got lost on } \\
& \text { her way.' }
\end{aligned}
$$

This is again quite similar to the facts reported from Malay. The foregrounding function of lah is also used to structure narrative texts (Hopper 1979:46). Lah appears on verbs describing events that constitute the main story line. These are events which are new and highly relevant to the story. Events that are not marked with lah are used to set the scene, they describe side-episodes of minor narrative relevance or parts of the event that are considered not so important. In the Gùrùntùm example (56), the episode ends with the girl (kado 'she') getting lost. This narrative turning point is indicated by the focus/foregrounding $a$ marker.

To conclude, in this section we argued that the focusing effect of the $a$ marker is also observed with events. The puzzling fact that non-presentational clausal focus marking is excluded from non-perfective sentences was analysed as a consequence of event foregrounding. Since an event or situation must be completed in order to be foregrounded, ongoing, overlapping or habitual events are unsuitable for foregrounding and therefore not suffixed with $a$. In this respect, Gùrùntùm constitutes another nice example for Hopper's universal implicational relation between foregrounding and perfectivity. 


\section{Conclusion}

In this article, we presented an in-depth analysis of focus marking in the West Chadic language Gùrùntùm. Focus in Gùrùntùm is marked morphologically by means of the pre-focal marker $a$. It is marked consistently across all syntactic constituents and across all aspects and tenses. It marks new information focus as well as other kinds of focus, such as selective, corrective or contrastive focus. It also appears in predicative and presentational constructions. The focus constituent can be either realised in its base-position, or it can be fronted. We speculated that the choice of position is dependent on the notion of noteworthiness, but this assumption has to be corroborated by future research. We also showed that Gùrùntùm exhibits focus ambiguity when it comes to predicate focus: focus is realised on the object even if the verb or the VP is focused. We proposed that focus ambiguity can be traced back to a syntactic restriction: Gùrùntùm has a bias for nominal focus marking, just as many other Chadic languages. We defended our analysis against a claim from the literature that $a$ is an aspectual marker of perfectivity. Evidence in favour of our proposal came from syntactic and semantic considerations. Finally, we showed that the affinity of sentence-final $a$ to perfective interpretations follows from $a$ 's nature as a foregrounding marker, both intra- and intersententially.

\section{References}

Beckman, Mary, and Janet Pierrehumbert. 1986. Intonational Structure in English and Japanese. Phonology Yearbook 3. 255-309.

Büring, Daniel. 2001. Let's Phrase It! Focus, Word Order, and Prosodic Phrasing in German Double Object Constructions. Competition in Syntax, ed. by Gereon Müller and Wolfgang Sternefeld, 67-105. Berlin: Mouton de Gruyter.

Büring, Daniel. 2006. Towards a Typology of Focus Realization. Ms. UCLA. 
Büring, Daniel and Rodrigo Gutiérrez-Bravo. 2001. Focus Related Word Order Variation Without the NSR: A Prosody-Based Crosslinguistic Analysis. Syntax at Santa Cruz 3, ed. by Séamas Mac Bhloscaidh, 41-58. Santa Cruz.

Comrie, Bernhard. 1976. Aspect. Cambridge: Cambridge University Press.

Eaton, Helen. 2005. Information Structure Marking in Sandawe Texts, Ms., SIL International.

Frajzyngier, Zygmunt. 2002. A Grammar of Hdi. Berlin: Mouton de Gruyter.

Givón, Talmy. 1988. The Pragmatics of Word Order: Predictability, Importance and Attention. Studies in Syntactic Typology, ed. by Michael Hammond, Edith A. Moravcsik and Jessica Wirth, 243-284. Amsterdam: John Benjamins.

Green, Melanie. 2004. Predication, Equation and Information Structure: Evidence from Hausa Copular Sentences Ms. University of Sussex.

Gundel, Jeanette. 1988. Universals of Topic-Comment Structure. Studies in Syntactic Typology, ed. by Michael Hammond, Edith A. Moravcsik and Jessica Wirth, 209-239. Amsterdam: John Benjamins.

Hartmann, Katharina and Malte Zimmermann. 2004. Focusing in Chadic - The Case of Tangale Revisited. Interdisciplinary Studies on Information Structure. Working Papers of the SFB 632, ed. by Shinichiro Ishihara, Michaela Schmitz and Anne Schwarz, 207-243. Potsdam: Universitätsverlag Potsdam.

Hartmann, Katharina and Malte Zimmermann. To appear. In Place - Out of Place? Focus in Hausa. On Information Structure, Meaning and Form, ed. by Kerstin Schwabe \& Susanne Winkler. Amsterdam: John Benjamins.

Haruna, Andrew. 2003. A Grammatical Outline of Gùrdùy / Gùrùntùm (Southern Bauchi, Nigeria). Köln: Rüdiger Köppe.

Herburger, Elena. 2000. What Counts. Focus and Quantification. Cambridge, MA: MIT Press.

Hoffmann, Carl. 1963. A Grammar of the Margi Language. London: Oxford University Press.

Hopper, Paul J. 1979. Some Observations on the Typology of Focus and Aspect in Narrative Language. Studies in Language 3/1.37-64. 
Hyman, Larry, Heiko Narrog, Mary Paster \& Imelda Udoh. 2002. Leggbó Verb Inflection: A Semantic and Phonological Particle Analysis. Proceedings of the 28th Annual Berkeley Linguistic Society Meeting. 399-410.

Jackendoff, Ray. 1972. Semantic Interpretation in Generative Grammar. Cambridge, MA: MIT Press.

Jaggar, Philip. 1988. Guruntum (gùrdùn) (West-Chadic B): Linguistic Notes and Wordlists. African Languages and Cultures 1(2).169-189.

Kenstowicz, Michael. 1985. The Phonology and Syntax of WH-Expressions in Tangale. Studies in the Linguistic Sciences 15.79-91.

Legendre, Geraldine. 2001. An Introduction to Optimality Theory in Syntax. Optimality-Theoretic Syntax, ed. by Geraldine Legendre, Jane Grimshaw, and Sten Vikner, 1-27. Cambridge, MA: MIT Press.

Lewis, David. 1975. Adverbs of Quantification. Formal Semantics, ed. by Edward L. Keenan, 3-15. Cambridge: Cambridge University Press.

Maina Gimba, Alhaji. 2000. Downdrift in Bole. UCLA Working Papers in Phonology 4, ed. by Adam Albright and Taehong Cho, 13-30. UCLA Department of Linguistics, LA.

Newman, Paul. 1977. Chadic Classification and Reconstructions. Afroasiatic Linguistics 5.1-42.

Partee, Barbara H. 1991. Topic, Focus and Quantification. Proceedings of SALT I, ed. by S. Moore and A. Wyner, 159-187. Ithaca, NY.

Pierrehumbert, Janet. 1980. The Phonetics and Phonology of English Intonation. Cambridge, MA: MIT, MIT dissertation.

Rooth, Mats. 1985. Association With Focus. Amherst: University of Massachusetts, UMass dissertation.

Rooth, Mats. 1992. A Theory of Focus Interpretation. Natural Language Semantics 1.75-116.

Schuh, Russell and Alhaji Maina Gimba. 2004. Draft Chapters and Sections for a Forthcoming Reference Grammar of Bole. UCLA. www. humnet. ucla.edu/humnet/aflang/Bole (Papers)

Schwarz, Florian. 2005. Ex Situ Focus in Kikuyu. Ms. Amherst: University of Massachusetts. 
Schwarzschild, Roger. 1999. Givenness, AvoidF and Other Constraints on the Placement of Accent. Natural Language Semantics 7.141-177.

Selkirk, Lisa. 1984. Phonology and Syntax. The Relation between Sound and Structure. Cambridge, MA: MIT Press.

Selkirk, Lisa. 1995. Sentence Prosody: Intonation, Stress, and Phrasing. Handbook of Phonological Theory, ed. by John Goldsmith, 550-569. Oxford: Blackwell.

Selkirk, Lisa. 2004. Bengali Intonation Revisited: An Optimality Theoretic Analysis in which FOCUS Stress Prominence Drives FOCUS Phrasing. Topic and Focus: Cross-linguistic Perspectives on Intonation and Meaning, ed. by Chungmin Lee, Matthew Gordon and Daniel Büring, $217-$ 246. Dordrecht: Kluwer.

Truckenbrodt, Hubert. 1999. On the Relation Between Syntactic Phrases and Phonological Phrases. Linguistic Inquiry 30.219-255.

Tuller, Laurice. 1986. Bijective Relations in Universal Grammar and the Syntax of Hausa. Los Angeles: University of California, UCLA dissertation.

Tuller, Laurice. 1992. The Syntax of Postverbal Focus Constructions in Chadic. Natural Language and Linguistic Theory 10.303-334.

Uhmann, Susanne. 1991. Fokusphonologie. Tübingen: Niemeyer.

von Fintel, Kai. 1994. Restrictions on Quantifier Domains. Amherst: University of Massachusetts, UMass dissertation.

Wolff, Ekkehard. 2003. Predication Focus in Chadic Languages. Topics in Chadic Linguistics, ed. by Dymitr Ibriszimow, Henri Tourneux and Ekkehard Wolff, 237-159. Köln: Rüdiger Köppe.

Zimmermann, Malte. 2006. Focus in Western Chadic: A Unified OT-Account. Proceedings of NELS 36, ed. by Chris Davis, Amy Rose Deal and Youri Zabbal, UMass at Amherst.

Katharina Hartmann

Humboldt Universität Berlin

Inst. f. dt. Sprache und Linguistik

Sitz: Hegelplatz 2

D-10099 Berlin

k.hartmann@rz.hu-berlin.de
Malte Zimmermann Humboldt Universität Berlin SFB 632 "Informationsstruktur" Sitz: Mohrenstr. 40-41 D-10099 Berlin malte.zimmermann@rz.hu-berlin.de 